\title{
OS AFORISMOS SOBRE O ABSOLUTO: SCHULZE CONTRA O "EVANGELHO” DE SCHELLING E HEGEL ${ }^{1}$
}

\section{THE APHORISMS ON THE ABSOLUTE: SCHULZE AGAINST THE "GOSPEL" OF SCHELLING AND HEGEL}

\author{
Lucas Nascimento Machado ${ }^{2}$ \\ Luiz Filipe da Silva Oliveira ${ }^{3}$
}

Recebido em: 05/2020

Aprovado em: 11/2020

\begin{abstract}
Resumo: Neste artigo, apresentar-se-á brevemente, não sem quaisquer contextualizações, o texto de Schulze, do qual também será oferecida aqui uma tradução, "Aforismos sobre o absoluto", onde ele desenvolve, em um estilo irônico — ou, nas palavras de Vieweg, "pseudoirônico" —, a sua crítica às filosofias da identidade de Schelling e de Hegel. Do mesmo modo, será indicado, em primeiro lugar, as distintas maneiras pelas quais Schelling e Hegel o recepcionaram — de modo que se revele a divergência entre ambos quanto à filosofia e quanto ao método filosófico, antes ocultadas a favor da adesão de ambos a um projeto filosófico semelhante em suas linhas mais gerais. Em segundo lugar, examinar-se-á quais seriam os elementos conceituais discutidos no texto de Schulze que seriam centrais à compreensão dessa divergência filosófica e metodológica entre Schelling e Hegel, e que culminarão em sua ruptura definitiva com a publicação da Fenomenologia do Espírito - . Acredita-se, desde já, que tais elementos conceituais podem ser encontrados, particularmente, no tratamento dos conceitos de forma, matéria (ou conteúdo) e determinação. De maneira mais específica, eles são vislumbrados na objeção, levantada por Schulze, de que toda concepção do absoluto baseada nos conceitos de forma e de conteúdo só poderia ser uma concepção relativa, pois não apenas a própria distinção entre conteúdo e forma seria meramente formal, como também qualquer conteúdo pensado em sua distinção e oposição em relação à forma, só poderá ser, ele mesmo, um conteúdo relativo e, portanto, formal. Essa crítica, concluir-se-á, será decisiva para o modo com que Hegel pensará o absoluto não mais apenas como substância, mas igualmente como sujeito.
\end{abstract}

Palavras-chave: Schulze, Hegel, Schelling, Filosofia da Identidade, Reflexão.

\begin{abstract}
In our paper, we make a brief presentation and contextualization of Schulze's text, of which we present here a translation, "Aphorisms about the absolute". In this text, Schulze develops, in an ironic style - or, in the words of Vieweg, pseudo-ironic - , his critique of the philosophies of identity Schelling and Hegel. In our exposition, we aim to point out, first, how, before the publication of the Aphorisms, Schelling and Hegel understood skepticism in general and evaluated Schulze's skepticism in particular. Next, we shall see how Schulze responded to Schelling and
\end{abstract}

\footnotetext{
${ }^{1}$ Partes desse artigo são versões revisadas e adaptadas de trechos do cap. 7 da tese de doutorado de um dos autores (MACHADO, 2020). Revisão técnica da tradução: Israel Meneses Santos Vilas Bôas, Mestrando na EFLCH Unifesp; E-mail: chrysotile@gmail.com

${ }^{2}$ Doutor em Filosofia pela Universidade de São Paulo (bolsa FAPESP e bolsa CAPES/DAAD sanduíche), mestre em filosofia pela Universidade de São Paulo; E-mail: lucasmachado47@gmail.com

3 Doutorando em Filosofia pela UFRGS (Bolsista CAPES), mestre em Filosofia pela UFJF; E-mail: luizfilipe3r@gmail.com
} 
Hegel's objections with his Aphorisms, and how the reception of this text by Schelling and Hegel was quite different - so different, in fact, that their disagreements about philosophy and the philosophical method begin to surface, where they were hidden before in favor of their adherence to a similar philosophical project in its more general lines. In the next step, we examine what are the conceptual elements discussed in Schulze's text that would be central to the understanding of this philosophical and methodological divergence between Schelling and Hegel, and which will culminate in their definitive rupture with the publication of the Phenomenology of Spirit. These conceptual elements we believe to be found, particularly, in the treatment of the concepts of form, matter (or content) and determination. Or, more specifically: in the objection, raised by Schulze, that any conception of the absolute based on the concepts of form and content could only be a relative conception, since not only the distinction between content and form is merely formal, but also any content, thought in its distinction and opposition to form, can only be relative and, therefore, formal content. We shall, then, conclude this criticism will be decisive for the way in which Hegel will come to think of the absolute not only as a substance, but also as a subject.

Keywords: Schulze, Hegel, Schelling, Identity Philosophy, Reflection

O puro só pode ser representado no impuro, e se tentares admitir o nobre sem o ordinário, ele será visto como o mais antinatural, o mais absurdo. Hölderlin ${ }^{4}$

\section{Introdução}

Diante do que sabemos hoje, um texto como o Aforismos sobre o Absoluto, de Gottlob Ernst Schulze, não nos mais poder ser ignorado na relevância que têm para a compreensão de momentos decisivos da história do idealismo alemão, e particularmente para as elaborações filosóficas maduras de Hegel. Sendo assim, em nosso artigo, fazemos uma breve apresentação e contextualização do texto de Schulze, de que apresentamos aqui uma tradução, Aforismos sobre o absoluto, onde ele desenvolve, em um estilo irônico - ou, nas palavras de Vieweg (1999, p. 232), pseudoirônico -, a sua crítica às filosofias da identidade de Schelling e de Hegel. Visamos a indicar, primeiramente, como antes da publicação dos Aforismos, Schelling e Hegel teriam compreendido o ceticismo em geral e avaliado o ceticismo de Schulze em particular. A seguir, veremos como Schulze responde às críticas de Schelling e Hegel ao seu ceticismo por meio de seus Aforismos, e como a recepção desse texto por parte de Schelling e de Hegel foi bastante distinta - de modo que começa a forçar a vir à superfície as suas divergências quanto à filosofia e ao método filosófico, antes ocultadas a favor de sua adesão a um projeto filosófico semelhante em suas linhas mais gerais. No passo seguinte, examinamos quais seriam os elementos conceituais discutidos no texto de Schulze que seriam centrais para a compreensão dessa divergência filosófica e metodológica entre Schelling e Hegel, e que culminarão em sua

\footnotetext{
${ }^{4}(1965$, p. 311).
} 
ruptura definitiva com a publicação da Fenomenologia do Espírito - elementos conceituais que acreditamos poder ser encontrados, particularmente, no tratamento dos conceitos de forma, matéria (ou conteúdo) e determinação. Mais especificamente: na objeção, levantada por Schulze, de que toda concepção do absoluto baseada nos conceitos de forma e conteúdo só poderia ser uma concepção relativa, pois não apenas a própria distinção entre conteúdo e forma seria meramente formal, como também qualquer conteúdo, pensado em sua distinção e oposição em relação à forma, só poderá ser, ele mesmo, um conteúdo relativo e, portanto, formal. Por fim, concluiremos apontando como essa crítica será decisiva para o modo com que Hegel passará a pensar o absoluto não mais apenas como substância, mas igualmente como sujeito.

\section{Schulze e a recepção do ceticismo por Schelling e Hegel}

Comecemos, então, por discutir a compreensão que Schelling e Hegel tinham do ceticismo em geral, e como avaliavam o ceticismo de Schulze em particular, antes da publicação dos Aforismos. A esse respeito, vale lembrar, primeiramente, que, durante muito tempo, o autor do Enesidemo foi lembrado pela bibliografia especializada apenas como um inquisidor do modo como Reinhold acreditou derivar da filosofia de Kant um princípio que unificasse as esferas do empírico e do transcendental, uma espécie de monismo metodológico ${ }^{5}$. Assim, Schulze teria ocupado a modesta posição de depurar os erros da possibilidade desta unificação, que ficaria mais conhecida na versão apresentada por Fichte. Isso se resume, grosso modo, naquela virada terminológica, a saber, na transição do princípio denominado Tatsache, apreendido pela filosofia elementar de Reinhold, para a famosa Tathandlung, que balizaria todo o desenvolvimento posterior da Doutrina da Ciência. ${ }^{6}$ Diante disso, parece não ser exagero dizer que a leitura e a pesquisa acerca da produção de Gottlob Schulze esteve na maior parte do tempo à sombra dos grandes iniciadores do idealismo alemão.

Em relação a essa posição, é provável que mesmo Schulze não censurasse a interpretação do Enesidemo como uma produção estritamente inquisidora, obra que foi tomada como metonímia para seu pensamento. Por mais que tivesse sido acusado de dogmatismo por Fichte em sua Resenha do Enesidemo, ${ }^{7}$ pô-la à luz de alguma teoria filosófica positiva parece

\footnotetext{
${ }^{5}$ Embora haja importantes exceções; vide, por exemplo, Bonaccini (2003, § 3.2).

${ }^{6}$ Para uma consideração mais apurada acerca de como a crítica de Schulze a Reinhold impactou o autor da Doutrina da Ciência, Cf. Breazeale, 2014a.

${ }^{7}$ Obra que têm duas traduções brasileiras. A primeira por Joãosinho Beckenkamp (2004, pp. 67-100) em Entre Kant e Hegel, e a seguinte por Ricardo Barbosa (2016, pp. 59-98) em Ceticismo e Criticismo.
} 
mesmo não corresponder às ambições da obra cujo autor talvez estivesse mais próximo da caricatura do cético feita por Kant: "o vigilante que conduz o raciocinador dogmático a uma saudável crítica do entendimento e da própria razão" (KANT, 2013, p. 615). Contudo, se o mesmo Kant ensina sobre a possibilidade de um pensamento crítico conter elementos propositivos, ainda que decepcionasse a própria faculdade da razão, estes, decerto, podem ser encontrados de forma mais nítida no desenvolvimento da produção teórica schulzeana em Crítica da filosofia teórica, publicado em 1801.

Contudo, tampouco o novo trabalho alcançou reconhecimento por seus próprios méritos, ao menos não por méritos positivos. Uma vez mais Schulze ocuparia uma posição ofuscada pela maneira como sua obra foi divulgada na boca de outros autores. Fala-se, dessa vez, de ninguém menos do que Hegel, haja vista a época em que ainda tateava uma resolução mais convincente para o novo projeto de filosofia que assumira com Schelling em Jena e posteriormente elabora uma resenha da nova obra muito menos amistosa do que a que Fichte fizera do Enesidemo. Contudo, tal reação não parece ser desproporcional à nova abordagem de Schulze que, se antes havia concentrado mais diretamente suas críticas a um episódio da herança do criticismo, e mesmo ao criticismo como um todo, pretendia agora encontrar a "falha hereditária" de toda filosofia teórica. Grosso modo, Schulze enfatizava a impossibilidade de qualquer filosofia teórica alcançar as causas incondicionadas de cada coisa condicionada uma vez que todo conhecimento repousava sob uma base subjetiva, particular, unilateral, tão logo, condicionada.

A resenha de Hegel, denominada Relação do ceticismo com a filosofia ${ }^{8}$ seria publicada no ano seguinte no Jornal crítico de filosofia; este é criado com a intenção de difundir seu projeto com Schelling de elaborar uma filosofia com base naquilo que começaram a chamar de especulação. A pretensão mais proeminente deste projeto seria demonstrar a possibilidade de um saber absoluto com base na razão. Ainda que as objeções de Hegel à obra de Schulze tenham chegado tardiamente no Brasil, é bem verdade que ganharam projeção na pesquisa por possibilitarem visualizar mais nitidamente a aplicação crítica do método especulativo da nova filosofia de Jena contra o que eles denominavam "saber da reflexão", "conhecimento reflexivo", "entendimento" etc. Com base na distinção entre o método especulativo e o método reflexivo, Hegel criticará a análise de Schulze, considerando-o não apenas o propagador do ceticismo

\footnotetext{
${ }^{8}$ Obra finalmente disponível em língua portuguesa. A realização desse feito deve-se a Joãosinho Beckenkamp (2019), que inclui essa tradução como anexo de uma obra inteira dedicada ao problema do ceticismo no idealismo alemão. Para uma análise mais detida desse artigo, da crítica que Hegel faz nele a Schulze e da relevância do ceticismo para a filosofia hegeliana, cf. MACHADO 2014 e OLIVEIRA 2019.
} 
dogmático, mas seu "chefe", aquele que "largou contra a fortaleza da filosofia" um "saco de m...” (HEGEL, 2019, p. 135).

Ainda que não seja possível falar de uma convergência completa no que Hegel e Schelling entendiam por filosofia especulativa, ambos provavelmente acreditavam que o acordo apareceria naturalmente no desenvolvimento de seus textos no Jornal, já que a principal característica desta era demonstrar a identidade necessária a tudo aquilo que o saber reflexivo entendia apenas como decomposto. De maneira oposta, a epistemologia natural da reflexão entendia a existência de singulares através de determinações particularmente organizadas de modo que os tornavam singulares subsistentes em si, resultando que todo ser é "um contraposto, condicionado e condicionante" (HEGEL, 1968, p. 17, tradução nossa). Diante dessa incapacidade da reflexão encontrar qualquer fundamento incondicionado em meio a essa infinidade de singulares aparecentes, Hegel ressalta que o cético verdadeiro, diga-se o antigo, seria levado a suspender seu juízo. Schulze, entretanto, o "primeiro lugar" na "preclara multidão de novos céticos", tomava essa realidade de coisas singulares aparecentes da reflexão como a única possível (HEGEL, 2019, p. 135). Nesse "balaio" ele também incluía a especulação, a saber, o âmbito da razão.

Já assimilando de certa forma aquela exigência declarada na Fenomenologia do Espírito (1807) de assumir como necessário ponto de partida da filosofia certa atitude natural da consciência - o saber da reflexão, que Schulze encarava como o único possível, e seus limites, como a prova cabal da aridez da filosofia teórica - Hegel aposta nessa improdutividade da reflexão para apontar o carecimento de uma forma mais perfeita do saber: a especulação. Dentro deste esquema, vemos o desenvolvimento ordenado de partes do primeiro projeto sistemático de Hegel em Jena, o qual é elaborado de acordo com uma estrutura bipartida. Por um lado, teríamos a lógica, local onde reinava as contradições do conhecimento reflexivo sob uma estrutura dialética que necessariamente levaria à metafísica, campo dedicado ao saber da razão, ou seja, à filosofia. A primeira parte, tão logo, é uma dialética que permanece negativa e cujo resultado é simplesmente cético. O ultrapassar dela é sua própria dissolução, ou seja, o campo especulativo da razão. Por isso, Hegel critica o ceticismo estanque de Schulze que se fixa no saber reflexivo como o único possível e não compreende que suas antinomias são exatamente a indicação da existência suprida pelo carecimento de um saber mais elevado. Era a isso que Hegel se referia quando apontou um "carecimento da filosofia" no escrito sobre a Diferença entre os sistemas filosóficos de Fichte e Schelling (1801). O aproveitamento do método dialético, bem como de suas consequências céticas, estaria em maior conformidade com o tipo 
de ceticismo praticado pelos antigos, dado que estes não se voltavam contra a razão, mas contra a possibilidade de um conhecimento derivado dos sentidos, pautado pelo senso comum e pelo entendimento.

De acordo com Rosenkranz, Hegel opera no Jornal Crítico "uma aniquilação do pseudoceticismo de Schulze, do senso comum de Krug, da filosofia de Rückert e Weiß, para a qual não é preciso pensar" (ROSENKRANZ, 1987, p. 409). De fato, pareciam emergir duas posições antagônicas no tocante às possibilidades de derivações teóricas de princípios kantianos. Por um lado, temos um partido que buscava a revalorização do saber do senso comum; por outro, com Schelling e Hegel, “o dualismo da experiência dá lugar ao monismo do sistema", contudo, "ironicamente ambos os movimentos são atribuídos a Kant" (COELHO, 2014, p. 169). Grosso modo, os primeiros estariam unidos por aquilo que Schulze resumiu como "fatos da consciência" em Crítica da filosofia teórica, isto é, todo saber é condicionado pelos limites do conhecimento de uma consciência e é restrito à consciência e dependente da mera relação com ela; já os segundos estariam unidos por aquilo que chamavam de especulação. Na verdade, esse antagonismo traduz perfeitamente a divisão derivada entre o dualismo da experiência e a visão monista de sistema que se originou após a morte de Kant. O fato era que, naquele momento, qualquer proposta inquisitiva mais peremptória a respeito da edificação de sistemas filosóficos bastava para ser conflagrada cética. ${ }^{9}$ Essa tendência havia sido captada por Reinhold: "Em nenhum outro momento o conceito de ceticismo na filosofia foi tão ambíguo e definido com tanta imprecisão, e nunca existiram tantos céticos imaginários e tão poucos céticos realmente filosóficos como agora" (REINHOLD, 1793, p. I). Contudo, é aqui que as diferenças entre os métodos filosóficos de Schelling e Hegel se tornam evidentes.

Em uma raríssima demonstração de convergência com essa negatividade positiva do ceticismo enquanto dialética, em Lições sobre o Método de Estudos Acadêmicos (1803) Schelling chama essa progressão na qual as determinações da reflexão são desenvolvidas rumo à unidade especulativa da razão de "ceticismo científico", cujo método era a dialética (SCHELLING, 1859c, p. 269). ${ }^{10}$ Tudo aponta que essa seria uma apropriação direta dos desenvolvimentos da filosofia hegeliana, uma vez que, em seu diálogo Bruno ou Sobre o

\footnotetext{
${ }^{9}$ Isso se deve principalmente à introdução de um certo ceticismo subjetivo baseado em Hume, e à leitura das ideias de Thomas Reid. Quem teve forte influência na divulgação dessas ideias foi Carl Friedrich Stäudlin, com sua principal publicação, Geschichte und Geist des Skepticismus, vorzüglich in Rücksicht auf Moral und Religion [História e espírito do ceticismo, principalmente em relação à moral e à religião] (1794).

${ }^{10}$ Vieweg, (2007, p. 133) também fala sobre Schelling ter se apropriado da diferença, realizada por Hegel, entre o ceticismo ruim, o ceticismo moderno de Schulze, e o ceticismo verdadeiro, o qual corresponde àquele dos antigos, nas Apresentações ulteriores de meu sistema de filosofia (1802) de Schelling.
} 
princípio divino e natural das coisas (1802), até então considerada a principal obra da chamada filosofia da identidade, Schelling se apropria da teoria dos arquétipos dos neoplatônicos, recalcitrante à dialética, para explicar a relação entre o conhecimento finito e o conhecimento absoluto. ${ }^{11}$ Apesar da referida menção, Schelling sempre preferiu ser modesto quanto ao papel da reflexão na contribuição aos resultados da razão. Sua filosofia se ocupava muito mais em demonstrar de que modo a absolutez seria irretocavelmente sustentada em meio a uma realidade de coisas finitas do que explicar a subsistência do finito em meio a essa absolutez. ${ }^{12}$

A divergência velada entre os dois residia na relação entre as determinações negativas finitas do entendimento e o saber absoluto produzido de modo especulativo pela razão. O método através do qual a razão acendia ao absoluto era chamado intuição intelectual (ou transcendental). Este método, por sua natureza peremptória acerca da capacidade de se alcançar um conhecimento incondicionado, foi tomado como metonímia para a filosofia da identidade de Jena, figurada nas pessoas de Schelling e Hegel. A questão, contudo, era que a maneira como ambos interpretavam o papel da reflexão na produção daquele saber alterava completamente o estatuto do método. A forma sistemática de Hegel diferia da tendência espiritualista de Schelling desde Jena. Foi por meio da metafísica, concebida por meio da inclusão das determinações da reflexão desenvolvidas na lógica, na intuição transcendental, que Hegel pretendeu construir não uma relação de oposição absoluta entre uma e outra, mas uma continuidade dada pela "construção" do absoluto na consciência. Na intuição intelectual de Schelling, essa construção seria dada no sentido oposto, a saber, na destituição da consciência em meio à imposição da indiferença completa na realidade absoluta. Schelling tornaria essa verve ainda mais explícita em 1802, no exame sobre Rückert e Weiß: “agora a perspectiva está aberta a outra filosofia [...] que exclui aqueles que não têm dons suficientes para se elevar à compreensão dos princípios" (SCHELLING, 1859b, p. 83).

Esta era a realidade diante da qual a nova filosofia de Jena, figurada na resenha de Hegel, recebe as críticas de Schulze. Schelling e Hegel, como vimos, convergiam no que diz respeito à possibilidade de alcançar um saber incondicionado, mas divergiam, ainda que implicitamente, quanto à forma como alcançariam esse saber. A convergência inabalável residia na convicção de que o método reflexivo não esgotava a capacidade da subjetividade, tampouco as limitações do entendimento afetavam as possibilidades da razão. Contudo, as marcas da não observância

\footnotetext{
${ }^{11}$ Sobre a origem da dialética Cf. Düsing, 1984, pp. 93-108.

${ }^{12}$ Para uma consideração acerca da possível divergência entre Schelling e Hegel já no período de colaboração no Jornal crítico de filosofia Cf. Oliveira, 2019, pp. 96-102.
} 
da distinção entre ambos os programas levariam a filosofia da identidade de Jena a um malentendido filosófico que geraria um impacto ainda não muito bem calculado na trajetória de Schelling e Hegel, por mais que já se tenha a certeza de que os impactos não tenham sido insignificantes. Ainda que a pesquisa já tenha considerado o episódio como um ponto marcante na história da relação dos dois autores, certamente seus impactos ainda não foram completamente medidos.

\section{A resposta de Schulze à filosofia da identidade, e o caos planejado: Os Aforismos sobre o} Absoluto e a sua recepção.

O princípio deste episódio configura-se na virtuosa forma como Schulze reage às críticas desferidas por Hegel em sua resenha do ceticismo. Com a contribuição pioneira de Kurt Reiner Meist (1993, pp. 192-230), em seu artigo "Sich vollbringender Skeptizismus”. G. E. Schulzes Replik auf Hegel und Schelling, importantes aspectos do embate esquecido entre a filosofia da identidade Jena e o ceticismo viriam à luz na bibliografia especializada. Grosso modo, o ceticismo de Schulze ganhava sobrevida nas discussões a respeito do desenvolvimento da filosofia especulativa de Jena para além da mera posição que Hegel destinou a ele em sua resenha. A resposta de Schulze pode ser encontrada nas publicações de dois de seus textos, um de 1803 e o outro de 1805, no jornal Neues Museum der Philosophie editado por Bouterwek. O primeiro foi intitulado Aforismos sobre o absoluto como único princípio da verdadeira filosofia, sobre o único modo possível de conhecê-lo, bem como sobre a relação de todas as coisas do mundo com ele; o segundo, O grande momento do pensamento cético sobre o conhecimento humano. ${ }^{13}$ Para Klaus Vieweg "ambos os tratados representam uma faceta importante da constelação filosófica nos primeiros anos do novo século" (VIEWEG, 2007, p. 134).

Além de Meist, Vieweg também teve um papel importante na divulgação da redescoberta das respostas de Schulze à resenha de Hegel. Inicialmente, em seu Philosophie des Remis (1999), esforça-se, em certo sentido, para desacreditar os copiosos adjetivos positivos aos quais Meist atribui ao texto de Schulze. Enquanto Meist chamava o texto de Schulze de "camuflagem brilhante", "sátira bem sucedida" (MEIST, 1993, p. 195-196), Vieweg, claramente utilizando o nome do jornal em que o texto de Schulze fora publicado, ao ironizar

\footnotetext{
${ }^{13}$ Para uma análise das críticas de Schulze no segundo Cf. Bicca, 2010, pp. 125-130.
} 
os adjetivos de Meist, diz que este "no esforço para livrar essas joias [de Schulze] do pó do museu, na maioria das vezes exagera no ponto, estilizando o nosso Hofrat como um grande ironista e encharcando-o de elogios" (VIEWEG, 1999, p. 222). O que torna a ironia de Vieweg mais fina é que aqui ele se utiliza da ambiguidade da palavra alemã Hofrat que, por um lado, faz referência ao pseudônimo "Hofrath" que Schulze utiliza na publicação posterior, $O$ grande momento do pensamento cético, e, por outro, pelo fato de que, em alemão, tal palavra poderia também significar alguém que seria um tipo de conselheiro privado para questões públicas, jurídicas, administrativas etc. Entretanto, em sua publicação posterior, Skepsis und Freiheit (2007), ele está mais disposto a considerar a posição defendida por Meist, isso, evidentemente, depois da publicação da primeira edição do Hegel-Handbuch (2003), onde Walter Jaeschke se refere ao episódio envolvendo os dois textos como "uma pós-história [da resenha de Hegel] desconhecida até recentemente, mas que agora foi descoberta por Kurt Rainer Meist, e que ao mesmo tempo representa uma etapa importante na pré-história da Fenomenologia do Espírito" (JAESCHKE, 2003, p. 135).

Os entusiásticos elogios de Meist referem-se ao primeiro dos textos publicados por Schulze. Ele salta à vista, e foi assim com Meist porque o escrito demonstra a maestria de seu autor em adaptar um método argumentativo no qual Hegel era famoso e que usara na resenha contra o próprio Schulze. Próximo da maiêutica socrática, este consistia em levar os argumentos de uma perspectiva a tal ponto que suas bases por si só ruiriam, demonstrando suas contrariedades e absurdos. Foi exatamente isso que Schulze fez no escrito de 1803. Não obstante, levara isso às últimas consequências, de modo que, conscientemente, planejando causar embaraços teóricos a respeito da autoria, publica o ensaio no anonimato. A escrita, por conseguinte, induziria um leitor desavisado a confundir sua autoria. No caso do texto de Schulze, confundir-se-ia a escrita de um autor considerado cético com alguém do "círculo filosófico de Schelling” (MEIST, 1993, p. 194).

Esta nomenclatura mais geral, de um possível "círculo filosófico de Schelling" é importante para demarcar de que forma a nova filosofia de Jena era concebida aos olhos de seus leitores. Que Schelling era o principal expoente é notável pela prontidão com que ele lidou com as questões teóricas que imediatamente surgiram da discussão acerca da herança kantiana, ganhando fama e notoriedade através da forma que propôs um complemento à filosofia de Fichte, pensador que mais se sobressaiu a partir daquelas disputas. A isso, soma-se também o dito de Düsing (1969, p. 106), para quem é permitido supor que, na divisão do trabalho colaborativo no Jornal Crítico, Schelling enxergava o então recém-chegado em Jena, Hegel, 
como aquele que desenvolveria o papel negativo de crítica e, assim, limparia o cenário para a acomodação do trabalho propositivo, isto é, positivo, para que ele, Schelling, apresentasse as principais diretrizes do novo sistema especulativo de filosofia, a saber, a filosofia da identidade. Que Schulze tenha tomado as principais argumentações teóricas de Schelling como base para suas críticas é, portanto, acertado, ainda que, sobre a resenha no Jornal Crítico, "desde o princípio não tenha havido qualquer dúvida a respeito da autoria de Hegel” (JAESCHKE, 2003, p. 133).

Schulze então incorpora em sua abordagem autocontraditória boa parte do arsenal especulativo da filosofia de Jena de modo que o organizasse de uma maneira nunca antes feita, nem por Hegel, nem por Schelling, como se aquelas fossem as consequências verdadeiras da filosofia especulativa em que ambos se baseavam para desferir suas críticas filosóficas, tais como aquela de que Schulze foi alvo, mas incorporando, desta vez, uma forma de escrita mais adequada, que Schlegel e Novalis já haviam tornado famosa: a forma aforismática. Diferente de sua Crítica da filosofia teórica, que podia ser encarada como uma obra propositiva, haja vista os elementos oriundos do ceticismo de Hume, desta vez ele não abre mão da utilização da ironia e recorre a uma abordagem essencialmente negativa. Em outras palavras, fazia jus, assim, à caracterização kantiana conferida ao cético que, sendo "uma espécie de nômades, que têm repugnância em se estabelecer definitivamente em uma terra, rompiam, de tempos a tempos, a ordem social" (KANT, p. IX). Contudo, a ordem que Schulze queria romper tampouco merecia essa alcunha. Além de ainda não ter se estabelecido em definitivo para além dos círculos de Jena, as aparentes convergências da filosofia especulativa de Schelling e de Hegel, como já mencionado, eram camufladas por uma diferença sutil, mas imperiosa. Talvez esse seja o motivo pelo qual ambos, a princípio, ignoraram a publicação. Uma resposta descoordenada poderia retirar a camuflagem e revelar antecipadamente as diferenças que existiam entre ambos.

O mal-entendido acerca da autoria só seria dissolvido em 1805 em uma declaração pública, decerto anônima, intitulada Missverständnisse, no então respeitado Leipzig LiteraturZeitung.

Diante do acúmulo de sistemas filosóficos, que nos parecem ser um mero jogo de ideias e de uma fantasia irrequieta, algumas boas mentes provavelmente já pensaram em se tornar criadoras de um novo sistema filosófico que, em conteúdo e forma, seria muito semelhante aos novos edifícios doutrinários, mas ao mesmo tempo os contradiria e, como eles, estaria em completa contradição com a razão sólida. Este pensamento está talvez perfeitamente expresso nos Aforismos sobre o Absoluto (no Neuem Museum de Bouterwek na $2^{\mathrm{a}}$ edição do primeiro volume, pp. 108-48) "Por um autor cujo nome não 
se vai agora dizer, mas tampouco se deve desconhecer". Agora é do conhecimento de todos que o Sr. Hofrath Schulze em Helmstädt é o autor deste ensaio. A tendência do mesmo, ainda que Bouterweck tivesse comentado que "por causa desses aforismos era de se esperar piadas literárias promissoras", certamente não escaparia ao leitor atento e imparcial (ANÔNIMO, 1805, pp. 92-93, tradução nossa).

Esse mesmo documento revela algumas confusões causadas pelo anonimato de Schulze. Dá o exemplo de um reitor de um Liceu de Munique, Kajetan Weiller, que queria incorporar o texto a um manual de suas palestras filosóficas, esforçando-se muito para "interpretar para a juventude o significado de frases intencionalmente sem sentido" (ANÔNIMO, 1805, p. 94). Em carta endereçada a Niethammer, datada de 4 de março de 1805, Hegel, por meio dessa mesma declaração anônima, publicada no Leipzig Literatur-Zeitung, demonstra conhecimento de que o autor de tais aforismos era Schulze, contudo não se prolonga acerca do assunto, limitando-se a comentar a raiva que alguns senhores ligados ao Liceu de Munique deviam estar sentindo tendo em vista "a veemência com que o plano escolar [de Weiller] era defendido" (HEGEL, 1952, pp. 93-94, tradução nossa).

Contudo, não foram apenas educadores e jovens que foram levados à confusão. $\mathrm{O}$ anonimato levaria o já famoso Reinhold a se embaraçar outra vez em um novo estratagema de Schulze, depois que se passaram vários anos desde o primeiro conflito entre os dois. O autor da já citada declaração afirma que Reinhold, na $6^{\text {a }}$ edição de seu Beyträge, dá indicações de que não havia entendido os reais objetivos do tratado, indicando não saber bem como que ele poderia estar ligado com alguma piada literária (cf. ANÔNIMO, 1805, p. 94). ${ }^{14}$ Tal como ocorreu com outros na época, este de fato chegou a acreditar que se tratava de alguém que havia acomodado em uma outra forma de apresentação escrita, e com conteúdo mais enervado, o que Schelling e Hegel diziam quando frequentemente se referiam ao absoluto, especulação, intuição etc.

Podemos dizer que esses desconfortos e embaraços teóricos aos partidários póskantianos da época significavam para Schulze um ponto triunfante. A visão de Meist sobre a atuação de Schulze como portador de "um ecletismo predominantemente não-autônomo" (MEIST, 1993, p. 196), parece verdadeira, pois, ao mesmo tempo em que acreditava estar levando a cabo o princípio do pensamento cético de Hume, que teria sido superado de modo não autêntico pelos pós-kantianos, propunha-se também o inquiridor cético que sempre se

\footnotetext{
${ }^{14}$ Ipsis litteris: "Aber wie Er, in einer früheren Anmerkung, die litterarischen Scherze zugleich mit dieser
} Abhandlung in Erinnerung bringen konnte, begreifen wir nicht” (REINHOLD, GS 7, p. 865). 
levanta como sombra a uma dada tese afirmativa à luz da razão, algo mais próximo ao espírito da Crítica da Razão Pura. Aceitar esse compromisso significava que Schulze acreditava estar também em consonância, em certo sentido, com a manutenção da letra kantiana, contra aquela corrupção que concebia estar sendo feita em nome do espírito daquela filosofia, principalmente por aqueles que confiavam derivar pretensas verdades rigorosamente fundamentadas erigindo filosofias candidatas a sistemas universalmente válidos. Em nome de tais desconfortos, por exemplo, Schulze, utilizando aquilo que Vieweg $(1999$, p. 232$)$ chama de pseudoironia, ${ }^{15}$ chega a dizer que seu ceticismo atua como "purgante" "diante da ilusão da verdade que a infilosofia produz no entendimento" (SCHULZE, 1803, p. 109; 1993, p. 339) ${ }^{16}$.

Isso está diretamente conectado à forma como Schulze encarou a pretensão hegeliana de incorporar a negatividade cética dentro de sua proposta especulativa com base na razão. Para ele, o efeito purgativo se refere exatamente à "capacidade" da razão de esvaziar as indigestas contradições produzidas pela reflexão no entendimento. Grosso modo, o método ex negativo que Hegel atribui ao ceticismo é comparado por Schulze a um purgante, capaz de expurgar todo material improdutivo produzido pela reflexão, demonstrando, então, a "inaptidão do entendimento para a filosofia" (SCHULZE, 1803, p. 110; 1993, p. 339). Dessa forma, Schulze interpreta o antagonismo entre sua própria filosofia e a filosofia especulativa de Jena com base nessa divisão entre entendimento e razão, reflexão e especulação. Em linhas gerais, cada um enxergava dogmatismo naquilo que não era si mesmo. Contudo, é sabido que essa generalização por parte de Schulze não é desprovida de problemas.

À vista disso, eis a principal inversão de valores suscitada por Schulze: se em sua resenha Hegel apontou o dogmatismo schulzeano em postular uma falha teórica hereditária no conhecimento, aquele, por sua vez, acusa a filosofia da identidade de se distanciar do conhecimento comum. Essa tendência se evidencia nas satíricas afirmações de que a filosofia é uma ciência inteiramente diferente de todas as outras (SCHULZE, 1803, p. 107; 1993, p. 338). No entanto, o que Schulze pretendia mascarar com seu anonimato e forma de escrita irônica, ou pseudoirônica, de certa maneira, era o seu apelo aos fatos da consciência desenvolvidos em sua Crítica da filosofia teórica. O método reductio ad absurdum pode ser encarado como a tentativa schulzeana de provar que os princípios dos quais Schelling e Hegel partiam para

\footnotetext{
15 É possível incluir isso também nas reservas que o texto inicial de Vieweg nutre a respeito do entusiasmo de Meist; ele prefere se referir à escrita de Schulze como uma "pseudoironia" alertando para a corrupção do sentido originário da "ironia" conforme indicada por Friedrich Schlegel (VIEWEG, 1999, p. 232).

${ }^{16}$ Referenciamos aqui a edição original da obra de Schulze, de 1803, a partir da qual fizemos nossa tradução, juntamente com a reimpressão mais recente, de 1993.
} 
alcançar o absoluto ainda se referiam àqueles mesmos princípios do entendimento reflexivo, tão logo extrapolavam dogmaticamente os limites do conhecimento humano.

\section{O núcleo da crítica de Schulze à filosofia da identidade: forma, conteúdo e determinação}

Tendo em vista a recepção dos Aforismos e a sua proposta geral, podemos, agora, passar a examinar mais minuciosamente o teor de sua crítica à filosofia identidade. De fato, de acordo com a exposição irônica de Schulze, para entender como a especulação poderia ultrapassar os caros limites do entendimento seria necessário estabelecer os meios pelos quais esse limite é afirmado tão logo a reflexão opere. Estes estariam resumidos "nos conceitos de determinável [Bestimmbaren] e de determinação [Bestimmung], de matéria [Stoffes] (ou conteúdo [Gehaltes]) e de forma [Form]" (SCHULZE, 1803, p. 112; 1993, p. 340).

De fato, como podemos ver, fica clara a importância dos conceitos de forma, de conteúdo e de determinação não apenas para uma interpretação posterior dessas filosofias, que, embora possa esclarecer algo sobre elas, não concerniria ao modo como elas foram interpretadas e discutidas em seu próprio tempo histórico. Antes, pode-se ver aqui como não apenas esses conceitos eram vistos como centrais para a compreensão dessas filosofias em sua própria época, mas também como eles são de fato utilizados para sintetizar as propostas dessas filosofias como um todo, ou, em outras palavras, são vistos como os seus conceitos mais fundamentais. É evidente que seria incorreto generalizar a compreensão de Schulze com o intuito de pensar que todos os autores da época viam esses conceitos do mesmo modo; todavia, o fato de que essa crítica tenha tido profunda influência em Hegel — e, como já se argumentou algures ${ }^{17}$, e do mesmo modo tornará a ser feito no presente artigo, desempenhou um papel decisivo no desenvolvimento de sua filosofia de maturidade - mostra como ela toca em um ponto que é visto como central por ao menos uma parte dos autores a que ela se dirige e, por isso mesmo, acaba sendo constitutiva para a compreensão do desenvolvimento interno de seu pensamento.

De fato, será por Schulze considerar que esses conceitos estão na base mesma da filosofia da identidade, o que o levará a concluir que ela não pode fornecer um conhecimento adequado do absoluto. Afinal,

Ainda que agora não se tragam também com toda clareza os conceitos de

\footnotetext{
${ }^{17}$ Machado 2020 e Oliveira, 2019.
} 
determinável e de determinação à consciência; ainda assim, depreende-se dos mesmos facilmente que eles só significam algo na oposição um ao outro e na relação de um com o outro - relação, porém, que não suspende [aufhebt] a oposição. Não se pode pôr nenhum determinável, ou nenhuma matéria, sem já ter posto uma determinação ou forma, em relação à qual primeiramente o determinável é um determinável ou a matéria é uma matéria. E igualmente, não se pode, inversamente, pensar nenhuma determinação ou nenhuma forma, sem já ter pensado um determinável ou uma matéria, da qual aquela é distinta e em relação à qual ela é primeiramente uma determinação ou uma forma. (SCHULZE, 1803, p. 113; 1993, p. 340, grifo nosso).

Forma e conteúdo, determinação e determinável, portanto, só são forma e conteúdo dadas as relações entre si. É por isso que qualquer coisa que seja pensada por meio desses conceitos, ou cujo pensamento tenha por base esses conceitos, não poderia nos fornecer um conhecimento senão daquilo que é relativo, e não daquilo que é em si mesmo. Assim

Pelo dito já se torna, porém, evidente por que se afirma que o entendimento, por consistir apenas em reflexão, é simplesmente incapaz de em algum momento se elevar à representação [Vorstellen] de um Em Si [Ansich] e Para Si [Fürsich], e que aquilo que ele pensa não tem subsistência [Bestand] ou realidade [Realität]. Porque, como acabaram de ver, e como depois enxergarão ainda melhor, os seus pertences consistem apenas em meras relações, ou em algo tal que só é primeiro e meramente por meio de e para um outro, ao qual, portanto, só pode ser atribuído um ser aparente (SCHULZE, 1803, p. 113; 1993, p. 340).

Assim, porém, Schulze se volta, de maneira certamente consciente, à questão que estava no cerne das preocupações da filosofia kantiana (em sua distinção entre lógica geral e lógica transcendental ${ }^{18}$ e das filosofias pós-kantianas (já desde Reinhold e de sua concepção do princípio de consciência como o fundamento real, e não meramente formal de nosso conhecimento), ${ }^{19}$ a saber: a busca por uma forma que pudesse determinar o seu conteúdo e, inversamente, de um conteúdo que fornecesse um fundamento real para a sua forma, de modo que garanta que o nosso conhecimento não consista em meras relações de pensamento, que dizem, por certo, a forma como nós devemos pensar algo, mas não o que esse algo efetivamente é em seu conteúdo. De fato, aqui se afirma nada mais, nada menos, que toda tentativa de estabelecer uma relação necessária entre forma e conteúdo, ou de fornecer um modo como um poderia ser fundamento do outro, nunca fornece um fundamento que não seja meramente relativo, pois,

\footnotetext{
${ }^{18}$ Cf. MACHADO, 2000, Cap.1; Eidam, 2000 e Lee 2004.

${ }^{19}$ Cf. Reinhold, 2000.
} 
Uma vez que matéria e forma (para permanecer aqui apenas no modo mais universal do pensamento) foram distinguidos e relacionados ambos um ao outro como opostos em algo; assim surge inevitavelmente a pergunta: como a matéria chegou a essa forma, ou como essa forma chegou àquela matéria? Mesmo que por meio do entendimento devais acreditar ter agora encontrado algo que traz forma à matéria ou esta àquela e liga ambas; então ainda teria de distinguir novamente matéria e forma e opor uma à outra nesse algo, pois ele deve ser um objeto-do-entendimento. Mas, assim, se renova a pergunta: o que deu forma à matéria, ou injetou esta naquela? (SCHULZE, 1803, p. 114; 1993, pp. 340-341).

Em outras palavras: todo fundamento concebido como o fundamento que liga forma e conteúdo de nosso conhecimento terá, por sua vez, de ter, ele mesmo, forma e conteúdo; todavia, uma vez que ele mesmo tem forma e conteúdo, temos de nos perguntar sobre como a relação entre a forma e o conteúdo desse fundamento seria possível, o que levanta, uma vez mais, o mesmo problema. É claro que, diante dessa objeção, já se pode imaginar com facilidade qual seria a resposta dada a Schulze por Fichte, e mesmo por Schelling, em função da maneira como concebem a relação entre forma e conteúdo no princípio de suas filosofias ${ }^{20}$ : que, no caso do fundamento real último de nosso conhecimento, não haveria um fundamento anterior a ele mesmo que estabeleceria a relação necessária entre a sua forma e o seu conteúdo. Antes, a forma e o conteúdo do fundamento estabeleceriam, eles mesmos e por si mesmos, sua relação necessária um com o outro, na medida em que ambos não seriam possíveis fora dessa relação e, portanto, que ambos se determinariam reciprocamente. Schulze, todavia, tem plena consciência dessa resposta possível, e, por isso, em uma nota a essa mesma passagem, observa que

A compreensão de que toda condicionalidade e incerteza tem o seu começo
com a distinção de matéria e forma, levou recentemente à tentativa de, por
meio da busca de um tal juízo no qual a matéria deve determinar a forma e a
forma, por sua vez, deve determinar a matéria, obter uma certeza
verdadeiramente imediata e existente por si mesma, ou um pretenso
conhecimento absoluto. Todavia, é fácil compreender que não é porque, em
um juízo, a forma do mesmo deve ser determinada pela matéria e esta deve
ser determinada por aquela, que a oposição de ambas é imediatamente
suspensa, na medida em que apenas por meio de sua oposição elas são forma
e matéria, e, assim, por meio do estabelecimento de que a forma determinaria
a matéria e esta aquela, ainda não se desfaz a pergunta: Como afinal, a
determinação recíproca de uma pela outra seria possível? Além disso, é
inegável que, se a forma é determinada pela matéria, ela consiste em algo
condicionado e, assim, também a matéria, se ela é determinada por meio da

${ }^{20}$ Cf. Schelling, 1985 e Fichte, 1988. 
forma. Mediante a junção de duas condicionalidades, porém, não vem a ser nenhuma incondicionalidade e nenhum absoluto, ou não se chega, pela indicação constante de uma relatividade à outra, além da esfera de tudo que é relativo (SCHULZE, 1803, pp. 114-115; 1993, p. 341, nota).

Aqui, já temos formulado o cerne do argumento que servirá de base para voltar à crítica da filosofia da identidade às filosofias da reflexão contra ela mesma e afirmar que ela própria ainda não escaparia dos limites da reflexão: mesmo onde forma e conteúdo são pensados como absolutamente inseparáveis, eles ainda são pensados como distintos e, por isso mesmo, como opostos um ao outro. Outrossim, aquilo que o conteúdo é enquanto conteúdo e aquilo que a forma é enquanto forma só é possível por meio da sua relação um com outro e, portanto, por meio da sua relação com aquilo que é distinto de si próprio, de modo que o conteúdo, enquanto conteúdo, e a forma, enquanto forma, são, necessariamente - por terem de se relacionar com algo distinto de si próprios para serem o que são - condicionados, mesmo quando essa relação é recíproca. Em suma: a distinção entre forma e conteúdo é, ela mesma, uma distinção formal, e o conteúdo, considerado em sua relação e oposição à forma, não consegue capturar nada mais além de uma mera relação de pensamento.

Isso, contudo, como foi mencionado, seria o modo de operar supremo da reflexão. A sagacidade de Schulze estaria em demonstrar a abordagem autocontraditória de uma doutrina que tentava estabelecer um conhecimento para além desses limites. Para isso seria necessário, então, seguir à risca sua explicação acerca da doutrina concernente ao "Evangelho do absoluto" (SCHULZE, 1803, p. 112; 1993, p. 340). O primeiro mandamento à observância deste, segundo Schulze, seria o de que o absoluto "nunca afunda no relativo, condicionado e limitado, mas paira eternamente acima disso tudo, e se mantém em sua própria completude e majestade" (SCHULZE, 1803, p. 132; 1993, p. 348), condição necessária de um conhecimento que se pretendia contrário aos condicionantes da reflexão. Mas, então, a pergunta que restava seria: o que nos levaria ao "átrio do Santíssimo" [Vorhof zum Allerheiligsten]? (SCHULZE, 1803, p. 131; 1993, p. 348).

Schulze pretende pôr em xeque a validade da nova filosofia de Jena por meio de respostas satíricas que elabora a essa questão. Faz isso para cultivar uma dúvida quanto à inspiração do texto: se de fato se tratava de um escrito filosófico ou se tinha alguma pretensão confessional religiosa de fundo. Para isso, utiliza uma série de metáforas retiradas da teologia, tais como luz e escuridão, transfiguração [Verklärung], bem-aventurança [Seligkeit], criação do mundo [Schöpfung der Welt]. Chega a dizer, por exemplo, que "a razão tem o sopro de Deus [Odem Gottes] em nossa natureza" (SCHULZE, 1803, p. 134; 1993, p. 349). Esta, em 
conjunção com a que afirma que o conhecimento "não deve ser buscado na terra, mas, como Prometeu, roubado diretamente do céu". (SCHULZE, 1803, p. 108; 1993, p. 338), tem, entre outras, provável inspiração na citação que Schelling faz em referência a Eschenmayer no escrito Sobre o verdadeiro conceito da filosofia da natureza (1801), aliás, em oposição ao próprio Schulze: "O princípio original que, segundo Baader, sopra [weht] do alto sobre a estátua morta de Prometeu e provoca a primeira onda na pulsão da natureza (a interação de seu dualismo) é a espontaneidade" (SCHELLING, 1859a, pp. 101-102). A referência a Franz Baader, uns dos que mais contribuíram para a introdução do pensamento teosófico na Alemanha da época, abriria ainda mais o flanco para o chiste de Schulze. Note-se também a referência ao mito de Prometeu, o titã que, na mitologia grega, roubou o fogo que emanava dos deuses e o deu aos homens, para que, assim, a humanidade pudesse desfrutar de um conhecimento inacessível às outras espécies de animais da criação. A alusão aqui é exatamente aos poderes que os idealistas de Jena atribuíam à razão em detrimento do entendimento: o "céu" em oposição à "terra". De modo geral, a escrita é organizada com o intuito de fazer com que alguém familiarizado com as filosofias de Schelling e Hegel pudesse encontrar elementos familiares revestidos com argumentações pitorescas.

O cerne da questão dizia respeito a se a razão se contrapõe aos elementos supremos do modo de pensar reflexivo, sob o qual cada coisa que existe podia ser pensada. Nesse sentido, a paródia de Schulze representa as consequências imediatas da filosofia da identidade de Jena como a doutrina do "nada absoluto".

O que são, porém, essas leis, por exemplo a lei segundo a qual esses objetos existem, no espaço, uns fora dos outros e, no espaço, uns depois dos outros, que cada um deles deve sempre a sua existência à efetividade [Wirksamkeit] de uma outra coisa, que eles todos se encontram em relação de ação recíproca um sobre o outro, contêm a ligação de uma forma com uma matéria a ela oposta etc. (SCHULZE, 1803, p. 139; 1993, p. 352).

A bem-aventurança suprema, da qual "que nenhum ouvido a escutou e nenhum olho a viu" (SCHULZE, 1803, p. 134; 1993, p. 349), referência clara à passagens bíblicas, ${ }^{21}$ não podia provir de outro ser que não o nada absoluto, no qual todas as coisas que são, em algum momento, já foram e a ele regressarão:

A partir disso, porém, já se conhece com completa clareza que elas se encontram em ligação contínua com o nada, e tem de consistir em meras

${ }^{21}$ Cf. Isaías, 64:4 e I Coríntios, 2:9. 
formas formadas a partir dele. Porque o ser verdadeiro não pode nunca se perder a partir de si mesmo e passar para o não-ser. Tudo, porém, que participa do nada, não consegue se manter e se salvar diante da transitoriedade, ou seja, diante da unificação com o nada. Isso porque tudo se esforça para retornar ao princípio do qual provém (SCHULZE, 1803, p. 140; 1993, p. 352).

De todo modo, parecia que as críticas de Schulze atingiam o âmago do princípio da identidade absoluta descoberto por Schelling. Vale lembrar que, por exemplo, no já citado, Sobre o verdadeiro conceito da filosofia da natureza (1801), Schelling exigia a abstração do próprio intuinte, descoberto por Fichte a partir de sua autoposição, como possibilidade de unificação dos dois campos, do espírito e natureza: "Tendo em vista a filosofia da natureza, reivindico a intuição intelectual conforme reivindicada pela Doutrina da Ciência; mas também exijo a abstração do intuinte nesta intuição" (SCHELLING, 1859a, pp. 87-88). Grosso modo, exigia a completa abstração da consciência, e, com ela, daqueles elementos sobre os quais o entendimento pensa algo. Para Schulze, a quem todo conhecimento nada mais é do que fatos da consciência, ou seja, mediados pelo entendimento, o que Schelling exigia era a completa nadificação de tais elementos, um campo sobre o qual não se pode extrapolar seus limites sem o risco de cair em uma especulação — na acepção mais vulgar da palavra — vazia acerca do nada absoluto. A principal conclusão satírica que Schulze desenvolveu a respeito das doutrinas de Schelling e de Hegel foi que suas consequências levariam à afirmação de que "tudo é nada, e nada é tudo" (SCHULZE, 1803, p. 141; 1993, p. 353).

\section{A resposta de Schelling e de Hegel aos Aforismos e a ruptura entre ambos}

Vejamos, agora, como Schelling e Hegel replicam aos Aforismos de Schulze de modo sintomaticamente distinto. Em relação à resposta de Schelling, vale lembrar que Schulze, fazendo jus à “doutrina do nada absoluto", havia afirmado que quanto ao seu princípio, ou seja, o absoluto, "não se pode acrescer a ele nenhum predicado [...]. Não se pode dizer que ele contenha uma quantidade, ou qualidade; que ele contenha uma matéria [Stoff] e uma forma [Form], ou algo semelhante" (SCHULZE, 1803, p. 122; 1993, p. 344). Por conseguinte, a maneira que Schelling encontrou de demonstrar sua indolência para com Schulze e, com isso, seu ponto de partida oposto de forma conceitual ao do ceticismo foi soberbamente recomendar a Schulze a resenha de Hegel sobre o ceticismo no Jornal Crítico que Schelling bem sabia ter sido a fonte motivadora do escrito de Schulze. 
Esta proposição também foi registrada pelo autor dos famosos Aforismos sobre o absoluto, os quais devem ser uma paródia da chamada filosofia mais recente, mas que foi fielmente reescrita por seus opositores. Entretanto, para compreender esta proposição, especialmente também nesta relação, é recomendável uma leitura mais detida do artigo 'Sobre a relação do ceticismo com a filosofia e suas diferentes modificações', publicado no Jornal Crítico de Filosofia, vol.1, p. 2. (SCHELLING, 2010, p. 100, nota).

A recomendação havia sido feita nos Aforismos para introdução à filosofia da natureza $(1805)^{22}$ e, talvez, tenha sido uma das últimas demonstrações públicas de consentimento entre os dois. Ela era sem dúvida derivada da posição que os dois autores atribuíam ao ceticismo na produção filosófica. Desde as Cartas filosóficas sobre o dogmatismo e criticismo (1795), Schelling havia encarado o verdadeiro cético como "aquele que acredita em uma "verdade infinita', ou melhor, 'verdade progressiva e construída por si mesma"' (SCHELLING, 1984, p. 17). Desta forma, em outros termos, o objetivo consistia em mostrar que "a escuridão que o cético busca transmitir sobre o conhecimento humano apenas revela a luz sem a qual nada poderia ser posto à sombra" (GARDNER, 2016, p. 329). Isso, sem dúvida alguma, influenciou Hegel em sua resenha do ceticismo, texto que Schelling agora indicava como fonte teórica ao seu adversário.

Naquela obra, Schelling buscava reafirmar seu princípio de que ao absoluto não cabem predicados, uma vez que "o predicado só é possível em oposição ao sujeito (uma oposição que é impensável em Deus), e também na medida em que, a cada predicado possível, pode ser oposto um outro" (SCHELLING, 2010, p. 56). O que estava por detrás dessa afirmação de Schelling, e que o afasta de Espinosa e o põe mais próximo da tradição do neoplatonismo e de Giordano Bruno, era sua necessidade de afirmação do universo como identidade absoluta, de modo que não lhe cabiam atributos. Afirmar atributos era afirmar predicados, afirmar predicados, para Schelling, significava, em certo sentido, afirmar a passagem do infinito ao finito, o que seria incompatível com a identidade originária. Desse modo, utilizando uma versão modificada da pergunta fundamental de Leibniz, ${ }^{23}$ Schelling questiona: "Por que nada não é, por que em geral algo é?" (SCHELLING, 2010, p. 77). Schelling chama a atenção para o fato de o contraposto ao nada não ser o "algo", mas sim o universo ou Deus. Em outras palavras, a relatividade contida no "algo" não faz jus à absolutez do nada ao qual somente o "todo" absoluto pode ser contraposto. Em meio à realidade do nada absoluto seria impossível algo ser, diferente

\footnotetext{
${ }^{22}$ De acordo com Jaeschke e Arndt (2012, p. 419), a preparação do texto deu-se em paralelo com a preparação do Sistema da filosofia em geral (1804), conhecido também como Sistema de Würzburg.

23 “Porque existe alguma coisa e não nada?" (LEIBNIZ, 2004, p. 158).
} 
da absolutez do universo, ou de Deus, a quem caberia a existência de tudo, de todas as coisas, exceto das coisas relativas e parciais (SCHELLING, 2010, p. 77). Schelling diria que aquilo que produz qualquer afirmação relativa acerca da realidade da coisa reside, em geral, na natureza do entendimento, ou seja, não dizia respeito às diferenças qualitativas. Dessa forma, entendemos a razão de Schelling citar por extenso em sua obra o ponto parodiado por Schulze por meio de seus Aforismos: "O reflexo (Abglanz) do absoluto na medida em que ele irrompe no Nada, o configura em fenômenos e, por meio daí, provoca o surgimento de uma variedade infinita de realidades aparentes" (SCHULZE apud SCHELLING, 2010, p. 94). ${ }^{24}$

A resposta de Schelling é peculiar, mas não inesperada:

\begin{abstract}
Por isto, um outro, que apresentou a doutrina do absoluto como a doutrina do nada absoluto, o fez melhor do que ele mesmo certamente pensava. Essa é com certeza a doutrina do nada absoluto das coisas, enquanto existentes de modo finito, as quais talvez apareçam a ele como a mais eminente realidade (SCHELLING, 2010, p. 95).
\end{abstract}

A questão era que se Schelling quisesse se manter altivo a respeito de seus princípios, não poderia abrir mão dessa exigência com a qual toda sua argumentação, com base na identidade absoluta, tinha seu fundamento, apesar de ele ter elaborado, nesse ínterim, uma variedade de novas formulações para seu princípio. Se não quisesse abrir mão desse princípio, não cabia a Schelling outra posição exceto reafirmar seus principais argumentos. Foi o que fizera em seus Aforismos para introdução à filosofia da natureza, primeira demonstração pública de conhecimento do texto de Schulze. Não é à toa que Jaeschke e Arndt afirmam que tal texto de Schelling, os referidos Aforismos, "poderiam ser mais adequadamente descritos como 'Aforismos sobre o absoluto' - porém da maneira como Gottlob Ernst Schulze havia chamado sua paródia de Schelling do ano 1803" (JAESCHKE; ARNDT, 2012, p. 420).

Uma crítica cética, como foi realizada no Enesidemo, ao princípio da consciência de Reinhold teria obtido o mesmo sucesso com o sistema de Schelling, "pois o princípio da identidade racional não serve para ele como uma lei do pensamento, [...] não é, portanto, um meio discursivo de derivar uma coisa de outra" (BREAZEALE, 2014b, p. 96). Assim, por um lado, poder-se-ia argumentar que o ponto que Schelling alcançara com a sua exigência de abstração absoluta dissolvia o campo de atuação de todo ceticismo, afinal, é com base no saber do entendimento que o cético arma seu arsenal de contra-argumentos. Por outro, em virtude de

\footnotetext{
${ }^{24}$ O mesmo pode ser encontrado no original em Schulze, 1803, p. 139; 1993, p. 351.
} 
sua natureza peculiar, com base na contraimagem completa a respeito de nossa forma de compreender a ordem de coisas no mundo, o autor não poderia se safar do elemento presente, mas não essencial, da contra-argumentação cética, que é a ironia, e, com isso, da possibilidade de vulnerabilidade de seu princípio ao método de reductio ad absurdum realizado por aqueles que não se põem no ponto por ele exigido.

Retorna-se aqui, então, ao possível ponto perene de divergência entre Schelling e Hegel, que a exposição de Schulze pode ter deixado mais claro, ao fazer Schelling se esforçar em revelar os princípios fundamentais de sua doutrina na elaboração de sua resposta ao ceticismo. A respeito disso, é válido ressaltar aqui um comentário que Kastner, recém-nomeado professor de Química em Heidel e ex-aluno de Schelling e de Hegel em Jena, fizera sobre os Aforismos de Schelling em carta a Hegel de 15 de novembro de 1805: "Gostei muito do tratado introdutório de Schelling sobre filosofia da natureza, mas — entre nós — para mim parece haver uma certa fraqueza no recuo [Zurückziehen] constante para trás do absoluto indistinto [undeutlich]" (KASTNER apud HEGEL, 1952, p. 102, tradução nossa). A essa altura, Schelling já havia dado demonstrações mais claras a respeito da necessidade de um rearranjo de sua doutrina, o que culminaria na superação, ou complementação, da filosofia da identidade explicitada com as Investigações sobre a essência da liberdade humana (1809), mas já pressentida em Filosofia e Religião (1804). Hegel, por outro lado, de acordo com a interpretação de Düsing, já havia ido além da metafísica da substância, adotada até então em conjunto com Schelling, e estabelecido uma metafísica da subjetividade que se manifesta pela primeira vez no Esboço de Sistema II de 1804/05 (DÜSING, 2004, pp. 187-194).

Com isso, constata-se que se, por um lado, até àquela altura, embora passando pelas críticas de Schulze, Schelling se manteve indelével a respeito de seu princípio incondicionado, por outro, na mesma época, percebe-se que aqueles moldes já não satisfaziam Hegel. Doravante, ele elabora mais consistentemente seu conceito de subjetividade absoluta no qual dispensava o conceito rígido de um absoluto indistinto como algo a que alguém poderia recuar, tal qual o relato de Kastner sobre a exposição de Schelling versava. Como vimos, a sátira de Schulze estava concentrada naquele ponto em que a filosofia da identidade pensava poder derivar um absoluto em si para além da constituição lógica de uma consciência. Dito de outro modo, essa identidade nunca estaria para além da própria reflexão, uma vez que toda identidade pressuporia alguma relação com seus relata, que, por sua vez, tinham, eles próprios, determinação, ou seja, a identidade pressupunha relação com algo distinto dela mesma, a menos que fosse tratada como o nada absoluto, como satiricamente fez Schulze. O reconhecimento 
que Hegel alcançou em 1804 com sua metafísica da subjetividade havia sido exatamente de que a filosofia da identidade sempre, seja por meio do conceito de indiferença absoluta de Schelling, seja por meio da negação da consciência mediante a substância absoluta do povo como em seu próprio Ensaio sobre o direito natural (1802), pressupunha ainda certo repúdio de conceitos necessários para distinguir, diferenciar, ou mesmo identificar as características das coisas. Até então, Hegel utilizava o conceito de substância como base para sua filosofia do Espírito. ${ }^{25} \mathrm{~A}$ partir, então, de 1804/05, Hegel começa a desenvolver, tal como já havia começado a fazer em Frankfurt, uma teoria da consciência como história idealista da consciência, contexto no qual o conceito de substância parecia não poder ser acomodado como antes. ${ }^{26}$

A nova configuração da filosofia do Espírito alcançada em 1804, cristalizada sob a égide da negação determinada - a forma conceitual do outro de si mesmo — não permitia Hegel se manter preso ao coerentismo do conhecimento, ou seja, à asseveração de pontos de vistas mais elevados, arcaísmo no qual ele havia fundamentado a distinção entre ceticismo verdadeiro, ao qual antigo é o caso paradigmático, e falso, personificado pelo ceticismo moderno, em sua resenha da obra de Schulze em 1801. A questão se torna apresentar uma justificação absoluta para o conhecimento, sem recorrer a nenhum coerentismo que pudesse ser reduzido às questões cosmológicas de primeira ordem, por exemplo, aos pontos de vista e visões de mundo (tal qual o saber da intuição intelectual se diferenciava da reflexão), mas formulando um saber que fosse organizado sob um sistema circular, um círculo do saber que se fechasse sobre seu próprio princípio. Supondo-se a herança recebida de Schelling, por um lado, da identidade fundamental entre matéria e forma, entre a forma da consciência e seu objeto, e, por outro, a herança fichteana da concepção dessa identidade em termos do para si, Hegel começa a compreender que uma forma de conhecimento unilateral reverberava no próprio saber daquilo que era construído para a consciência, ou seja, um absoluto tampouco incondicionado, mas relativo, tal qual o critério por meio do qual se asseverava alcançá-lo; no caso da filosofia da identidade,

\footnotetext{
${ }^{25}$ Isso pode ser visto mais claramente no Ensaio sobre o direito natural, quando se define o Espírito como um dos atributos da substância (cf. HEGEL, 1968, p. 433; 464), e no Esboço de sistema I (1803/04), ao dizer que até mesmo o Espírito era a própria substância (cf. HEGEL, 1968, p. 268; 314; 315).

${ }^{26}$ Dessa forma, é correto dizer com Harris que Hegel já havia alcançado a certeza da necessidade da crítica ao formalismo - sinônimo de esoterismo - de Schelling desde 1804 (cf. HARRIS, 2014, p. 58). Isso estaria de acordo, por exemplo, com as teses de autores canônicos como Dieter Henrich, para quem, no interstício de produção ienense, "dos textos que sobreviveram, a teoria do absoluto como Espírito se encontra pela primeira vez plenamente desenvolvida na Lógica e Metafísica de 1804/05 [Esboço de sistema II]” (HENRICH, 1980, p. 118), mas também de autores mais contemporâneos, como Kenneth Westphal, que afirma que "só no verão de 1804 Hegel reconheceu que sua própria filosofia, também, deve evitar a questão contra visões filosóficas alternativas" (WESTPHAL, 2000, p. 288). A respeito da originalidade que se apresentava em Hegel por volta de 1804, esta pode ser observada pela importância que Westphal dedica ao texto Zwei Anmerkungen zum System publicado como suplemento do Esboço de sistema II, Cf. Westphal, 2000, pp. 287-291.
} 
um certo tipo de intuição, seja transcendental ou intelectual, para a qual faltava o caráter constitutivo da reflexão ainda preservado na filosofia de Fichte. Era preciso elevar-se rumo ao critério absoluto. O resultado mais acabado que ele alcança com isso é que a consciência seria concebida como a que reflete sobre si mesma por meio de sua relação negativa com um outro, em que ela, tal qual, conteria em si mesma o oposto ao qual se relacionava negativamente. Essa autorreferencialidade da consciência por meio do outro de si mesmo, que se traduz no que ele chama de Espírito, não poderia ser suprida apenas por meio do conceito de substância. Por caminhos outros, Hegel começou a pensar seu conceito de negação determinada.

No entanto, apesar dessas particularidades prévias, sabe-se que o rompimento entre Schelling e Hegel só viria à luz com a publicação da Fenomenologia do Espírito, em 1807, embora tal obra já estivesse parcialmente pronta desde 1806. É nesse ponto específico da denúncia do formalismo, cujo absoluto indistinto era ensejado, que a pesquisa tem encontrado, se não uma inspiração, a observância por parte de Hegel da necessidade de uma nova forma de combater os argumentos do ceticismo, uma "autorrevisão" (JAESCHKE, 2003, p. 136). Essa “autorrevisão" passava então por reconhecer a contribuição do instrumento - e, portanto, da forma - para o alcance do resultado, - isto é, do conteúdo - concebido pela filosofia da identidade como a "essência": "Se se diz que a forma é igual à essência, é por isso um equívoco pensar que o conhecimento pode ser satisfeito com o Em-si ou a essência, mas dispensar a forma" (HEGEL, 1980, p. 19, tradução nossa). Tal como a essência aqui está para o absoluto e a forma para a consciência, a primeira está para o objeto e a segunda para o conhecimento, na devida ordem. Pelo contrário, Hegel então nega que os conceitos que sustentam a individualidade de cada coisa no conhecimento, como, em especial, o próprio conceito de determinação, devem ser abolidos em prol de sua unidade. Dito de outro modo, nega-se que entre o conhecimento e seu objeto, entre essência (ou seja, conteúdo) e forma, absoluto e consciência, uma negação simples possa ser excogitada para que se tornem um só. É mister, ademais, lembrar que Schulze havia demonstrado a impossibilidade de uma identidade absoluta, uma identidade incapaz de levar em conta a subsistência de seus relata.

Dessa forma, com a alegação de que "é a reflexão que faz do verdadeiro um resultado, mas que ao mesmo tempo suprassume essa oposição ao seu vir-a-ser” (HEGEL, 1980, p. 20, tradução nossa), Hegel consuma o resultado mais importante para a ideia de um "ceticismo autocompletante", um ceticismo que se apresenta de modo imanente reavaliando o saber da consciência e dando as bases para o desdobramento de seu estado natural. O ceticismo age contra a afirmação do conhecimento dogmático, que subjaz à convicção natural da consciência 
humana, emergindo de modo imanente e intrínseco à consciência, tal qual toda e qualquer pretensão de conhecimento que dela emerja. Assim, a verdade que o ceticismo traz à luz é que todo saber naturalizado não passava de mera teorização, de perspectiva unilateral a respeito da coisa.

Compreende-se, portanto, por que o absoluto indistinto de Schelling, exatamente por excluir a reflexão ao apostar todas as fichas em um "tiro de pistola" para alcançar o absoluto, que Kastner havia chamado de indistinto, é caracterizado por Hegel como "a noite em que todas as vacas são negras" (HEGEL, 1980, p. 17, tradução nossa). ${ }^{27}$ Essa sentença representa o epítome dos argumentos que Hegel estabelece no Prefácio de sua Fenomenologia contra a possibilidade de um absoluto indistinto, isto é, contra o "formalismo" que ele diz que "a filosofia dos novos tempos denuncia e despreza (mas que nela renasce)" (HEGEL, 1980, p. 17, tradução nossa), e que expunha qualquer filosofia às contra-argumentações céticas. Foi diante disso que Vieweg afirma que "Hegel teve de supor que o colega [Schelling] nunca havia entendido realmente a intenção e o ponto de seu idealismo absoluto, assim como seu projeto de levar a cabo o ceticismo (como a única estratégia de imunização contra ele)" (VIEWEG 1999, p. 231, tradução nossa). Contudo, segundo Jaeschke “essa autocompressão programática da Fenomenologia havia sido moldada por anos de controvérsia com Schulze, e, nesse aspecto, seu ceticismo - imperfeito aos olhos de Hegel — tem uma significância não negligenciável para a sua concepção." (JAESCHKE, 2003, p. 136, tradução nossa). É diante disso que podemos afirmar que a maneira como ambos lidaram com as questões levantadas por Schulze foi determinante para pôr os dois filósofos em posições completamente distintas e irremediáveis.

De fato, se pudermos, aqui, sintetizar o que nos parece ser o núcleo das questões levantadas por Schulze em sua crítica, diremos que ela põe Hegel diante do seguinte impasse fundamental: a distinção entre forma e conteúdo fatalmente resultava que o próprio conteúdo se tornava algo meramente formal, e por isso, um "nada absoluto" — daí a acusação levantada por Hegel na Fenomenologia do Espírito de que a filosofia da identidade incidia numa concepção formalista. Pode-se especular sobre por que as objeções de Schulze não impressionaram Schelling do mesmo modo que Hegel. Como já foi dito, acreditamos que o fato de Schelling não atribuir nenhum papel constitutivo à reflexão no conhecimento do absoluto seria inseparável desse fato. Afinal, diante de qualquer conceito que Schulze afirmasse

\footnotetext{
${ }^{27}$ Nas palavras de Meist, "no Prefácio, Hegel despacha Schelling, aquele que antes era seu companheiro de caminhada, devido à sua contraposição irrefletida e que parecia prematura contra um crítico tão duro e perspicaz como Schulze, com as famosas palavras, já mencionadas, sobre uma noite escura com a presença de vacas" (MEIST, 1993, p. 208).
} 
ser um conceito do entendimento ou da reflexão, Schelling poderia simplesmente afirmar que esse conceito, tomado do ponto de vista da reflexão, podia, certamente, conter uma oposição, mas não a conteria caso fosse considerado uma vez mais do ponto de vista da razão ou da especulação, nas quais não há oposição alguma. De fato, a própria inseparabilidade entre forma e conteúdo da identidade absoluta fazia com que Schelling pensasse haver uma forma de conhecimento que não fosse a forma da reflexão e, portanto, que toda objeção lançada à reflexão como forma de conhecimento não se aplicasse à forma de conhecimento do absoluto.

Com Hegel, porém, como se abordou, a reflexão tem um papel constitutivo para o conhecimento que a razão tem de si mesma e do absoluto, mesmo que esse papel constitutivo seja ainda, no período de Jena, o da sua autonegação ou da sua suspensão por meio de si mesma $^{28}$. Em todo caso, esse papel constitutivo se deveria ao fato de que não haveria outra forma de conhecimento - no sentido estrito de forma ${ }^{29}$ - senão a forma da reflexão. Por isso, Hegel distinguia a reflexão que se torna razão da reflexão que degenera em entendimento. ${ }^{30} \mathrm{~A}$ crítica de Schulze, porém, teria mostrado para Hegel que a reflexão, ao negar-se a si própria, não chega a nenhum conteúdo distinto de si mesma; antes, tudo o que ela faz é, novamente, produzir um produto da reflexão, uma mera relação que, como abstração de toda oposição entre termos, era, ainda assim, uma espécie de ‘terceira oposição', ou de 'oposição de segundo nível', isto é, uma 'oposição a toda oposição'.

Bem se pode, assim, entrever como, ao mesmo tempo em que a crítica de Schulze mostrava que a reflexão não podia efetivamente chegar ao conhecimento de algo distinto de si

\footnotetext{
${ }^{28}$ Cf. Hegel, 1968, pp. 15-20.

${ }^{29}$ Razão justamente pela qual, para Hegel, a intuição transcendental como saber do absoluto não podia ser compreendida como uma "forma", mas, pelo contrário, resultava do processo no qual a forma se negava enquanto forma e advinha conteúdo - embora, no período do Differenzschrift, Hegel ainda concebesse esse conteúdo o qual a forma advinha como sendo anterior e dado independentemente do processo da forma tornar-se conteúdo, concepção que mudará, precisamente, com a Fenomenologia do Espírito.

${ }^{30}$ Assim, pode-se ver claramente também como é verdade que, tal como afirma Harris e como já fora mencionado, o problema da intuição intelectual e de como conceber sua relação com a reflexão era o problema com que Hegel já se ocupava "desde que ele provocou o rompimento decisivo entre Schelling e Fichte por meio do ensaio da Diferença", mesmo que, desse modo, Hegel não pretendesse "provocar um rompimento entre si mesmo e Schelling" (HARRIS, 2014, p. 65), ainda que tal rompimento tenha se mostrado inevitável. Por outro lado, julgase acertada uma radicalidade maior do que Harris, quando afirma que "Na Fenomenologia, assim como no restante de sua vida, Hegel estava tentando prover a filosofia da Identidade Absoluta com um método mais adequado, tanto de demonstração quanto de exposição" (Ibid.). Isso porque tal afirmação parece pressupor, justamente, que a diferença de compreensão do absoluto se daria apenas no nível de sua demonstração ou exposição; mas, se é verdade que, como o próprio Harris afirma mais adiante, para o Hegel de maturidade, "o processo de nosso vir a conhecer o absoluto era o próprio movimento de autoconstituição do absoluto" (Ibid.), então a diferença de demonstração e exposição tem de ser também uma diferença de concepção do absoluto, de modo que não se pode dizer que o Hegel de maturidade ainda se veja como um defensor da filosofia da Identidade Absoluta que, não por acaso, não mais será por ele identificada ao próprio absoluto, mas sim apenas à sua determinação mais inicial e abstrata, certamente necessária como início, mas inadequada para conceber o absoluto em sua efetividade e realização plena enquanto absoluto.
} 
mesma, fazendo com que o projeto de juventude de Hegel chegasse a um impasse, essa crítica forneceria, ao mesmo tempo, a chave para que Hegel possa reformular a sua própria ideia de como a forma, ao negar a si mesma, tornar-se-ia o seu próprio conteúdo: em virtude do fato de que, desse modo, ela não se torna um conteúdo que seria dado anteriormente a si própria e distinto de si mesma, mas, antes, é apenas assim que seu conteúdo é primeiramente dado. Assim, a distinção entre forma e conteúdo que só tornaria possível um conhecimento meramente formal do último, ou, dito de outro modo, que faria com que o próprio conteúdo acabasse sendo meramente formal, seria eliminada: a forma não é forma porque se relaciona com algo distinto e exterior a si mesma, mas sim porque ela se torna ela mesma distinta de si mesma, sem se tornar idêntica a algo que já existiria fora dela. Está dado, assim, o princípio metodológico que levará Hegel a conceber, por fim, “o verdadeiro não como substância, mas sim igualmente como sujeito" (HEGEL, 1980, p. 18, tradução nossa).

\section{Conclusão}

No que diz respeito a este episódio de disputa entre a filosofia da identidade de Jena e o ceticismo de Schulze, estes são os frutos mais imediatos e conclusivos que a pesquisa tem encontrado e com a qual acredita-se poder ter contribuído com o que aqui foi apresentado. Por um lado, o episódio é importante o suficiente para ser lembrado em meio às explicações acerca das motivações que levaram dois até então grandes amigos, Schelling e Hegel, ao distanciamento teórico que jamais seria desfeito. Por outro, marcante por dar sobrevida às produções literárias de Schulze para além do Enesidemo, a um crítico que se mostrou cirúrgico em tornar explícitas as inconsistências de uma doutrina que, pode-se dizer, da parte de Hegel, seria revisada e, de Schelling, no mínimo, complementada.

\section{Referências}

ANÔNIMO. Missverständnisse. In: Leipzig Literatur-Zeitung. Intelligenzblatt. n. 6, 1805, pp. 92-95.

BECKENKAMP, J. Ceticismo e idealismo alemão. São Paulo: Edições Loyola, 2019.

BÍBLIA SAGRADA. Tradução João Ferreira de Almeida. São Paulo: Sociedade Bíblica do Brasil, 1969.

BICCA, L. O ceticismo de Schulze como crítica do idealismo pós-kantiano. O que nos faz pensar, v. 19, n. 28, pp. 111-130, 2010. 
BONACCINI, J. A. Kant e o problema da coisa em si no idealismo alemão. Rio de Janeiro: Editora Relume Dumará, 2003.

BREAZEALE, D. A Resenha do Enesidemo de Fichte e a Transformação do Idealismo Alemão In: Revista SKÉPSIS, n. 11, 2014a, pp. 111-132.

Philosophical construction in Philosophy of Identity, In: OSTARIC, L. (Org.). Interpreting Schelling: Critical Essays. Cambridge University Press, 2014b, pp. 91-119.

COELHO, H. S. A Humanização da Experiência no auge da Filosofia Clássica Alemã. Revista Ética e filosofia política, v. 1, n. 17, 2014, pp. 165-181.

DÜSING, K. Das Problem der Subjektivität in Hegels Logik: systematische und entwicklungsgeschichtliche Untersuchungen zum Prinzip des Idealismus und zur Dialektik. Bonn: Felix Meiner Verlag, 1984.

Spekulation und Reflexion: Zur Zusammenarbeit Schellings und Hegels in Jena. In: Hegel-Studien 5. 1969. pp. 95-128.

Von der Substanzmetaphysik zur Philosophie der Subjektivität. Zum Paradigmenwechsel Hegels in Jena. In: KIMMERLE, H. (Ed.). Die Eigenbedeutung der Jenaer Systemkonzeptionen Hegels: Gemeinsame Tagung der Internationalen Hegel- Gesellschaft Und der Internationalen Hegel-Vereinigung. Erasmus Universität Rotterdam. De Gruyter, 2004, pp. 187-199.

EIDAM, H. Dasein und Bestimmung: Kants Grund-Problem. Berlin/New York: de Gruyter, 2000.

FICHTE, J. G. Resenha do Enesidemo. In: BECKENKAMP, J. Entre Kant e Hegel. Porto Alegre: EDIPUCRS, 2004, pp. 67-100.

. Resenha do Enesidemo. In: BARBOSA, R. Ceticismo e Criticismo: a ideia de uma ciência da ciência em geral. Rio de Janeiro: Ed. PUC-Rio, 2016, pp. 59-98.

Sobre o conceito da doutrina da ciência ou da assim chamada filosofia. Tradução: Rubens Torres Rodrigues Filho. In: Os pensadores. São Paulo: Editora Nova Cultural, 1988.

GARDNER, S. Fichte and Schelling: The Limitations of the Wissenschaftslehre? In: JAMES, D.; ZÖLLER, G. (Org.). The Cambridge Companion to Fichte. Cambridge: Cambridge University Press, 2016, pp. 326-349.

HARRIS, H. S. O Desenvolvimento Intelectual de Hegel até 1807. In: Hegel. BEISER, F. (Org.). São Paulo: Ideias e Letras, 2014, p. 37-65.

HEGEL, G. W. F. Differenz des Fichte'schen und Schelling'schen Systems der Philosophie. In: Jenaer Kritische Schriften, Gesammelte Werke, vol. 4, Hamburg: Felix Meiner, 1968.

Ueber die wissenschaftlichen Behandlungsarten des Naturrechts, seine Stelle in der 
praktischen Philosophie, und sein Verhältnis zu den positiven Rechtswissenschaften. In: Jenaer Kritische Schriften, Gesammelte Werke, vol. 4, Hamburg: Felix Meiner, 1968.

. Jenaer Systementwürfe I. Gesammelte Werke, vol. 6. Hamburg: Felix Meiner, 1968. . Jenaer Systementwürfe II. Gesammelte Werke, vol. 7. Hamburg: Felix Meiner, 1971. 1980. Phänomenologie des Geistes. Gesammelte Werke, vol. 9. Hamburg: Felix Meiner, Briefe von und an Hegel: Bände 1. 1785-1812. Hamburg: Felix Meiner, 1952.

Relação do ceticismo com a filosofia (1802). In: BECKENKAMP, J. Ceticismo e idealismo alemão. São Paulo: Edições Loyola, 2019, pp. 135-189.

HENRICH, D. Absoluter Geist und Logik des Endlichen. In: Hegel-Studien, Beiheft 20. Bonn: Bouvier, 1980, pp. 103-118.

HÖLDERLIN, F. Sämtliche Werke. Kleine Stuttgarter Ausgabe. Briefe, v. 6. Stuttgart: Kohlhammer, 1965.

JAESCHKE, W. Hegel Handbuch. Stuttgart: J.B Metzler Verlag, 2003.

JAESCHKE, W.; ARNDT, A. Die Klassische Deutsche Philosophie nach Kant: Systeme der reinen Vernunft und ihre Kritik 1785-1845. CH Beck, 2012.

KANT. I. Crítica da Razão Pura. Tradução de Manuela Pinto dos Santos e Alexandre Fradique Morujão. Lisboa: Fundação Calouste Gulbenkian, 2013.

LEIBNIZ, G.W. Princípios da natureza e da graça fundados na razão. In: Discursos de metafísica e outros textos. Tradução de Tessa Moura Lacerda. São Paulo: Martins Fontes, 2004.

MACHADO, L. N. A forma determinante: determinação, forma e conteúdo no Idealismo Alemão. Tese de Doutorado. São Paulo [s.n.], 2020.

Hegel e a relação entre ceticismo e filosofia: ceticismo e o problema da autodeterminação no idealismo alemão. Dissertação de Mestrado. São Paulo [s.n.], 2014.

MEIST, K. R. Sich vollbringender Skeptizismus. G. E. Schulzes Replik auf Hegel und Schelling. In: JAESCHKE, W. (Ed.). Transzendentalphilosophie und Spekulation: Der Streit um die Gestalt einer ersten Philosophie (1799-1807). Hamburg: Meiner Verlag, 1993.

OLIVEIRA, L. F. S. Identidade e Ceticismo em Hegel: A Filosofia de Jena em face das objeções céticas. Dissertação de Mestrado. Juiz de Fora [s.n.], 2019.

REINHOLD, K. L. Beyträge zur leichtern Übersicht des Zustandes der Philosophie beym Anfange des 19. Jahrhunderts. Sechstes Heft. In: Beyträge zur leichtern Übersicht des Zustandes der Philosophie beym Anfange des 19. Jahrhunderts. Gesammelte Schriften, vol. 7, Berlin: Schwabe Verlag, 2020, pp. 749-867. 
The Foundation of Philosophical Knowledge. In: Between Kant and Hegel: Texts in the Development of Post-Kantian Idealism (orgs. George di Giovanni e H.S. Harris). Indianapolis/Cambridge: Hackett Publishing Company, 2000.

Über den philosophischen Skeptizismus. Vorrede. In: HUME, D. David Humes Untersuchungen über den menschlichen Verstand. Tradução Tennemann, Jena: Verlag der akademischen Buchhandlung, 1793.

ROSENKRANZ, K. Geschichte der Kant'schen Philosophie. Steffen Dietzsch (Hrsg). Berlin: Akademie-Verlag, 1987.

SCHELLING, F.W.J. Ueber den wahren Begriff der Naturphilosophie und die richtige Art ihre Probleme aufzulösen. In: Sämmtliche Werke. Vierter Band. Stuttgart und Augsburg: JG Cotta'scher Verlag, 1859a.

. Rückert und Weiß, oder die Philosophie zu der es keines Denkens und Wissens bedarf. In: Sämmtliche Werke. Fünfter Band. Stuttgart und Augsburg: JG Cotta'scher Verlag, 1859b.

Vorlesungen über die Methode des akademischen Studiums. In: Sämmtliche Werke. Fünfter Band. Stuttgart und Augsburg: JG Cotta'scher Verlag, 1859c.

. Über die Möglichkeit einer Form der Philosophie überhaupt. In: Ausgewählte Schriften, Volume I. Baden-Baden, Suhrkamp, 1985.

Aforismos para introdução à filosofia da natureza e aforismos sobre filosofia da natureza. Tradução Márcia Gonçalves. Rio de Janeiro: Ed. PUC-Rio, 2010.

Cartas filosóficas sobre o dogmatismo e o criticismo. Coleção Os Pensadores, $3^{\mathrm{a}}$ ed. Tradução Rubens Rodrigues Torres Filho. São Paulo: Abril Cultural, 1989.

SCHULZE, G. E. Aphorismen über das Absolute. In: BOUTERWEK, F. (Ed.). Neues Museum der Philosophie und Litteratur. Bd. 1, H. 2. Leipzig: Gottfried Martini, 1803, pp. 107-148. Reimpresso In: JAESCHKE, W. (Ed.). Transzendentalphilosophie und Spekulation. Quellen: Der Streit um die Gestalt einer ersten Philosophie (1799-1807). Hamburg: Meiner Verlag, 1993, pp. 338-355.

VIEWEG, K. Philosophie des Remis: Der Junge Hegel und das Gespenst des Skepticismus. Munique: Wilhelm Fink Verlag, 1999.

Skepsis und Freiheit: Hegel über den Skeptizismus zwischen Philosophie und Literatur. Munique: Wilhelm Fink Verlag, 2007.

WESTPHAL, K. R. Kant, Hegel and the Fate of "the" Intuitive Intellect. In: SEDGWICK, S. (Ed). The Reception of Kant's Critical Philosophy. Fichte, Schelling, and Hegel. Cambridge: Cambridge University Press, 2000, pp. 283-305. 